\title{
Interrelationship between Ectoparasites and Wild Rodents from Tijucas do Sul, State of Paraná, Brazil
}

\section{Darci Moraes Barros-Battesti/ ${ }^{+}$, Márcia Arzua*, Pedro Marcos Linardi**, José Ramiro Botelho**, Ives José Sbalqueiro***}

Laboratório de Artrópodes, Instituto Butantan, Av. Vital Brazil 1500, 05503-900 São Paulo, SP, Brasil *Museu de História Natural Capão da Imbuia, Departamento de Zoológico, Prefeitura de Curitiba, PR, Brasil

**Departamento de Parasitologia, Instituto de Ciências Biológicas, Universidade Federal de Minas Gerais, Belo Horizonte, MG, Brasil ***Departamento de Genética, Universidade Federal do Paraná, Curitiba, PR, Brasil

Sixteen species of ectoparasites were collected from 50 wild rodents, from August 1990 to August 1991, in an area of Araucaria augustifolia forest, in the municipality of Tijucas do Sul, State of Paraná, Brazil. Ectoparasites infested $98 \%$ of the rodents, with the highest indices of infestation found in the drycool season. Species that occurred in single or multiple infestations were recorded. Ectoparasite/host associations were significant $(p<0.01)$ for Gigantolaelaps wolffsohni/Oryzomys nigripes, Polygenis pradoi/Oxymycterus $s p$. and Amblyopinus sp./Oxymycterus $s p$. The following represent new host records: Polygenis (Polygenis) tripus from Akodon serrensis and Hoplopleura sciuricola from Sciurus aestuans. New geographic records are given for two species of flea and one sucking lice.

Key words: ectoparasites - mites - fleas - sucking lice - staphylinid beetles - wild rodents

In Brazil, the greatest amount of information on ectoparasites of small wild mammals has been obtained from municipalities of the State of Minas Gerais: Viçosa (Whitaker Jr \& Mumford 1977), Caratinga (Botelho 1978), Belo Horizonte (Linardi et al. 1984, Botelho \& Linardi 1996), Juiz de Fora (Linardi et al. 1987), Tiradentes (Lopes et al. 1989) and Serra da Canastra National Park (Whitaker Jr \& Dietz 1987), with simultaneous records of mites, fleas and lice. Other Brazilian records of ectoparasites on wild mammals include Ilha Grande, State of Rio de Janeiro (Guitton et al. 1986), Ilha de Maracá, State of Roraima (Linardi et al. 1991a) and Florianópolis, State of Santa Catarina (Linardi et al. 1991b).

Concerning Paraná, except for previous studies of Guimarães (1945), Ribeiro (1966/1967), and Barros and Baggio (1992) on mammal ticks, only the municipalities of Mandirituba and Foz do Iguaçu have been studied in relation to the simultaneous occurrence of ectoparasites, even though Barros-Battesti and Arzua (1997) have recently presented a list of ectoparasites from marsupials in some of this state's biomes.

\footnotetext{
This work was supported in part by Conselho Nacional de Desenvolvimento Científico e Tecnológico (CNPq). ${ }^{+}$Corresponding author. Fax: +55-11-815.1505. E-mail: dbattesti@hotmail.com Received 16 January 1998 Accepted 13 July 1998
}

This study adds new information on ectoparasites from wild rodents in Paraná, in relation to the intensity and prevalence of infestation by host, the associations of ectoparasites, as well as the frequency of the ectoparasites on the respective hosts.

\section{MATERIALS AND METHODS}

The municipality of Tijucas do Sul is located in southern Paraná $\left(25^{\circ} 55^{\prime} \mathrm{S}, 45^{\circ} 24^{\prime} \mathrm{W}\right)$, Curitiba uplands sub-region (Maack 1968), where in the past sub-tropical forests of Auracaria augustifolia were predominant. Today these forests are reduced to small patches forming mosaics with agriculture and stockbreeding areas. The area of study, located in the Panagro farm, is constituted by three woods separated among themselves by 12 year-old Pinus elliotti and forming a dividing strip of 500 to 1,000 $\mathrm{m}^{2}$.

The wild rodents were captured in an isolated wood of altered primary forest with strong regeneration. From August 1990 to August 1991, during eight field phases, 30 live traps baited with corn and peanut paste were used, for three consecutive nights/phase, for a total of 720 traps/night capture effort. The capture success was $6.9 \%$. After anesthetizing with ether, ectoparasites were recovered from the rodents by combing and brushing. Tweezers were used when necessary. After preservation in $70^{\circ}$ ethanol, they were mounted on slides for taxonomic identification.

Although exhibiting an ample spectrum of ecological adaptations, some Cricetidae present similar morphological characters. For this reason, ro- 
dents were karyotyped to provide precise host identification. Chromosomes were obtained from bone marrow using Ford and Hamerton's (1956) technique. G-banding was obtained by trypsin treatment (Seabright 1971) with some modifications reported by Sbalqueiro and Nascimento (1996).

The ectoparasite-host association was evaluated by the $\mathrm{c}^{2}$ test. Significant associations were also analyzed by the coefficient of interspecific association (C), expressed in Southwood (1971). For each pair of species, the quantitative values ranging from +1 (complete positive association) to -1 (complete negative association) permit comparisons among different ectoparasite host associations. Two species $\boldsymbol{A}$ and $\boldsymbol{B}$, compared in a 2 x 2 contingency table give the following alternatives: $(\boldsymbol{a})$ presence of both species; $(\boldsymbol{b})$ presence of $\mathrm{A}$ and absence of B; (c) absence of A and presence of B; (d) absence of both species. In $\boldsymbol{n}$ samples, when $\boldsymbol{a d}$ is greater than $\boldsymbol{b c}$ the association is positive, with the coefficient and respective standard error being calculated by the formula:

$$
C_{A B}=\frac{a d-b c}{(a+b)(b+d)} \pm \sqrt{\frac{(a+c)(c+d)}{n(a+b)(b+d)}}
$$

The indices of infestation for Acari and Siphonaptera were calculated by the arithmetic mean to stipulate the infestation dimension in the studied area.

Representative specimens of ectoparasites and skins and skulls of hosts were deposited in the Museu de História Natural Capão da Imbuia, Curitiba, Paraná, Brazil. Prostigmata and Astigmata mites were not surveyed in the present work, but the skin collection of the museum represents future research opportunities.

\section{RESULTS AND DISCUSSION}

In total, 885 ectoparasite specimens representing 16 species were taken from 50 cricetid rodents. Rhopalopsyllinae Siphonaptera nomenclature follows the proposal of Linardi and Guimarães (1993).

Except for Sciurus aestuans L. and Nectomys squamipes (Brants), the other cricetid species presented the following karyotypes, whereas NA means number of autosomal arms: Akodon sp. $(2 \mathrm{n}=44 / \mathrm{NA}=44)$, Akodon montensis (Thomas) $(2 \mathrm{n}=24 / \mathrm{NA}=42)$, Akodon serrensis (Thomas) $(2 \mathrm{n}=46 / \mathrm{NA}=46)$, Bolomys lasiurus (Lund) $(2 \mathrm{n}=34$ / NA=34), Oryzomys flavescens (Waterhouse) $(2 \mathrm{n}=64 / \mathrm{NA}=66)$, Oryzomys nigripes (Olfers) $(2 \mathrm{n}=62 / \mathrm{NA}=82)$ and Oxymycterus $\mathrm{sp} .(2 \mathrm{n}=54$ / $\mathrm{NA}=64)$.

Species of ectoparasites and their respective hosts are shown in Table I. Comparing the results with those previously found for the municipalities of Mandirituba and Foz do Iguaçu (Barros et al. 1993) it can be seen that, while the mean intensity of ectoparasites is similar to that of the two municipalities (17.7), the total prevalence is higher, reaching almost all of the captured rodents $(98 \%)$.

For Siphonaptera, Polygenis rimatus was the most abundant, with 33\% of the total of fleas collected in $32 \%$ of rodents, being more frequent on A. serrensis (57\%) and Oxymycterus sp. (37\%) (Tables I, II). Except for Polygenis tripus, whose geographical distribution includes caatinga scrub, steppe, savanna and Atlantic forest areas, the other flea species are common in A. angustifolia forests (Linardi 1987).

The Parasitiformes acari infestation was dominant when compared to other ectoparasite groups. Androlaelaps rotundus was the most frequently occurring species among 748 acari (55\%), occurring on $52 \%$ of the rodents (Tables I, II), with $A$. serrensis the most infested host: $78 \%$ (Table I). Previous studies have shown $A$. rotundus at a prevalence of $93.5 \%$ on A. arviculoides (Linardi et al. 1987), $71.4 \%$ on A. cursor (Linardi et al. 1991b), and in all A. serrensis captured (Barros et al. 1993). The specimens of Amblyomma (Ixodidae) were not identified accurately for they are immature. The three larva and one nymph were similar to the description of A. cajennense reported by Amorim and Serra-Freire (1996). Horses usually infested with this tick were, sometimes, observed in the trails between the woods. Although the specimens of Macronyssidae mites are similar to ones in the genus Lepronyssoides, here they were only listed by the family.

Amblyopinus sp. were more frequent on Oxymycterus sp. (62\%), with few examples captured on Akodon species (Table I). Amblyopinini species are common on rodents and marsupials, although they also occur on bats and sloths (Seevers 1955, Timm \& Ashe 1987) and are difficult to differentiate at the species' level. Ashe and Timm (1987) consider Amblyopinini as mutualists, instead of true parasites. In the present study, the specimens only occurred during the cold-dry season being more collected over their hosts hair than fixed. Specimens of Amblyopinus sp. on rodents from the Juréia Ecological Station, State of São Paulo, were collected by Bergallo (1991) mainly during the dry season. This author observed that the specimens had their mandibles fixed on their hosts hair base without, in spite of that, causing skin bruises.

The rodent species diversity and frequencies during the months of study are listed in Table III. Except for October 1990 and March 1991, Oxymycterus sp. was captured in all months, at the 
TABLE I

Ectoparasites collected on 50 wild rodents from Tijucas do Sul, State of Paraná, Brazil, from August 1990 to August 1991

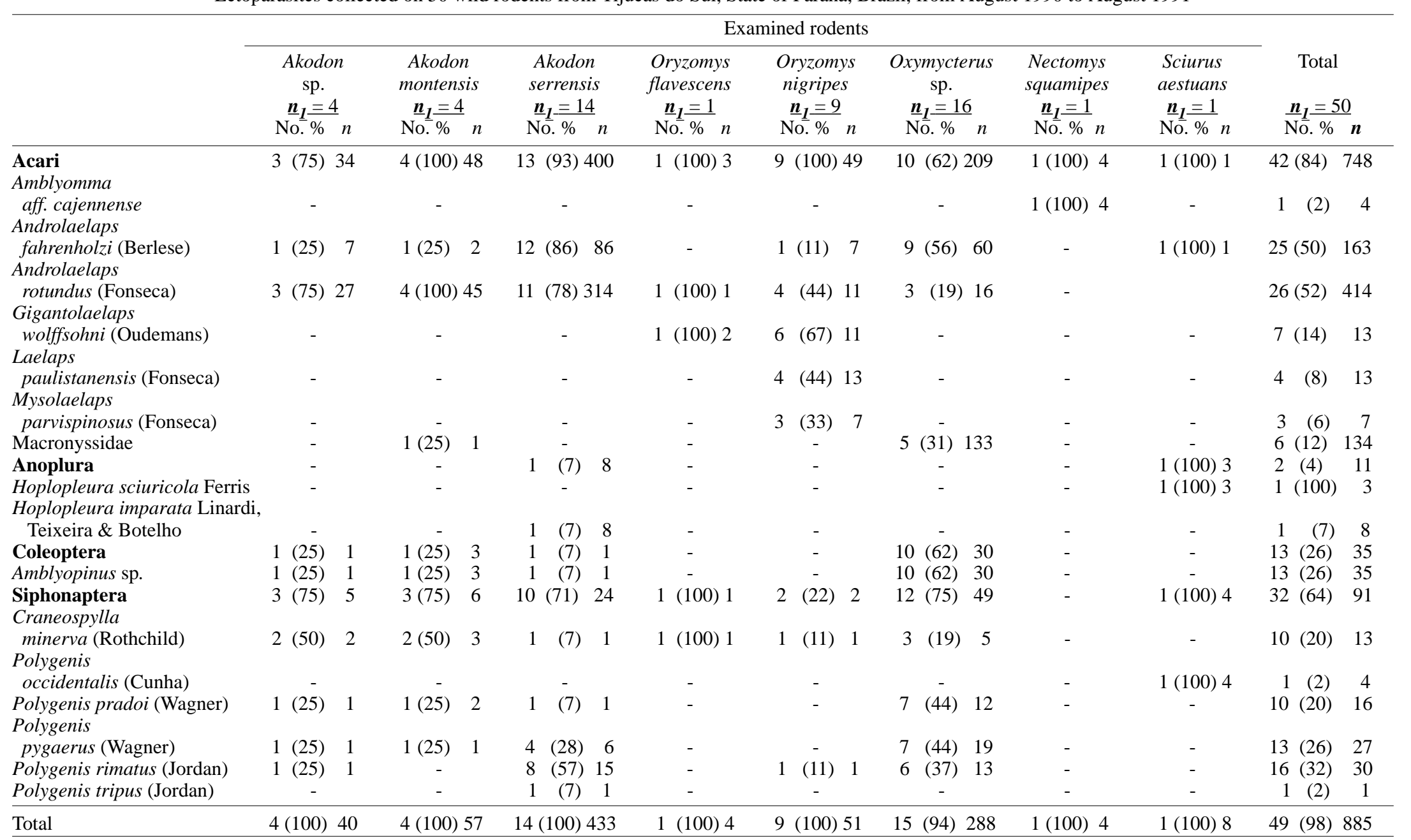

$n_{1}$ : number of hosts examined; $n$ : number of ectoparasites collected; No.: number of infested rodents. 


\section{TABLE II}

Number and (\%) of Acari and Siphonaptera collected between 1990 and 1991 in Tijucas do Sul, State of Paraná, Brazil

\begin{tabular}{|c|c|c|c|c|c|c|c|c|c|}
\hline & \multicolumn{9}{|c|}{ Months } \\
\hline & Aug'90 & Oct'90 & Nov'90 & Dec'90 & Mar'91 & Apr'91 & Jun'91 & Aug'91 & Total \\
\hline $\begin{array}{l}\text { Acari } \\
\text { Amblyomma }\end{array}$ & $59(8)$ & $48(6)$ & $179(24)$ & $84(11)$ & $9(1)$ & $302(40)$ & $37(5)$ & $30(4)$ & 748 (89) \\
\hline $\begin{array}{l}\text { aff. cajennense } \\
\text { Androlaelaps }\end{array}$ & - & - & - & - & - & - & $4(100)$ & - & $4(1)$ \\
\hline $\begin{array}{c}\text { fahrenholzi } \\
\text { Androlaelaps }\end{array}$ & $19(12)$ & $4(2)$ & $12(7)$ & $9(6)$ & - & $106(65)$ & $13(8)$ & - & $163(22)$ \\
\hline $\begin{array}{l}\text { rotundus } \\
\text { Gigantolaelaps }\end{array}$ & $32(8)$ & $44(11)$ & $136(33)$ & - & - & $168(40)$ & $20(5)$ & $14(3)$ & $414(55)$ \\
\hline $\begin{array}{l}\text { wolfhsoni } \\
\text { Laelaps }\end{array}$ & $2(15)$ & - & - & - & $3(23)$ & - & - & $8(62)$ & $13(2)$ \\
\hline $\begin{array}{l}\text { paulistanensis } \\
\text { Mysolaelaps }\end{array}$ & $3(23)$ & - & - & - & $6(46)$ & - & - & $4(31)$ & $13(2)$ \\
\hline parvispinosus & $3(43)$ & - & - & - & - & - & - & $4(57)$ & $7(1)$ \\
\hline Macronyssidae & - & - & $31(23)$ & $75(56)$ & - & $28(21)$ & - & - & $134(18)$ \\
\hline $\begin{array}{l}\text { Siphonaptera } \\
\text { Craneopsylla }\end{array}$ & $9(10)$ & $4(4)$ & $7(7)$ & $12(13)$ & - & $33(36)$ & $13(15)$ & $13(15)$ & $91(11)$ \\
\hline $\begin{array}{c}\text { minerva } \\
\text { Polygenis }\end{array}$ & $5(39)$ & - & - & $1(8)$ & - & $2(15)$ & $3(23)$ & $2(15)$ & $13(14)$ \\
\hline $\begin{array}{l}\text { occidentalis } \\
\text { Polygenis }\end{array}$ & - & - & $4(100)$ & - & - & - & - & - & $4(4)$ \\
\hline $\begin{array}{l}\text { pradoi } \\
\text { Polygenis }\end{array}$ & $1(6)$ & $2(13)$ & - & 3 (18) & - & $6(37)$ & $2(13)$ & $2(13)$ & $16(18)$ \\
\hline $\begin{array}{l}\text { pygaerus } \\
\text { Polygenis }\end{array}$ & - & $1(4)$ & $1(4)$ & $3(11)$ & - & $13(48)$ & $3(11)$ & $6(22)$ & $27(30)$ \\
\hline $\begin{array}{l}\text { rimatus } \\
\text { Polygenis }\end{array}$ & $3(10)$ & $1(3)$ & $1(3)$ & $5(17)$ & - & $12(40)$ & $5(17)$ & $3(10)$ & $30(33)$ \\
\hline tripus & - & - & $1(100)$ & - & - & - & - & - & $1(1)$ \\
\hline Total & $68(8)$ & $52(6)$ & $186(22)$ & 96 (12) & $9(1)$ & $335(40)$ & $50(6)$ & $43(5)$ & 839 (100) \\
\hline
\end{tabular}

TABLE III

Number and (\%) of rodents captured between 1990 and 1991 in Tijucas do Sul, State of Paraná, Brazil

\begin{tabular}{|c|c|c|c|c|c|c|c|c|c|}
\hline \multirow[b]{2}{*}{ Species } & \multicolumn{8}{|c|}{ Months } & \multirow[b]{2}{*}{ Total } \\
\hline & Aug'90 & Oct'90 & Nov'90 & Dec'90 & Mar'91 & Apr'91 & Jun'91 & Aug'91 & \\
\hline $\begin{array}{l}\text { Akodon sp. } \\
\text { Akodon }\end{array}$ & - & - & - & - & - & 1 & 1 & 2 & $4(8 \%)$ \\
\hline $\begin{array}{l}\text { montensis } \\
\text { Akodon }\end{array}$ & 1 & 1 & 1 & - & - & - & 1 & - & $4(8 \%)$ \\
\hline $\begin{array}{l}\text { serrensis } \\
\text { Oryzomys }\end{array}$ & 3 & 2 & 3 & - & - & 6 & - & - & $14(28 \%)$ \\
\hline $\begin{array}{l}\text { flavescens } \\
\text { Oryzomys }\end{array}$ & - & - & - & - & - & - & - & 1 & $1(2 \%)$ \\
\hline nigripes & 2 & - & - & - & 1 & - & - & 6 & $9(18 \%)$ \\
\hline $\begin{array}{l}\text { Oxymycterus sp. } \\
\text { Nectomys }\end{array}$ & 2 & - & 1 & 2 & - & 3 & 3 & 5 & $16(32 \%)$ \\
\hline $\begin{array}{l}\text { squamipes } \\
\text { Sciurus }\end{array}$ & - & - & - & - & - & - & 1 & - & $1(2 \%)$ \\
\hline aestuans & - & - & 1 & - & - & - & - & - & $1(2 \%)$ \\
\hline Total & $8(16 \%)$ & $3(6 \%)$ & $6(12 \%)$ & $2(4 \%)$ & $1(2 \%)$ & $10(20 \%)$ & $6(12 \%)$ & $14(28 \%)$ & $50(100 \%)$ \\
\hline
\end{tabular}


frequency of $32 \%$, with the greatest number of captures in August 1991.

The following results were significant by the application of the $\mathrm{c}^{2}$ test $(\mathrm{p}<0.01)$ and positive coefficient of interspecific association $(C>0.50)$; the results were significant for the following associations: Gigantolaelaps wolffsohni/Oryzomys nigripes $\left(\mathrm{c}^{2}=20.23 ; \mathrm{C}=0.83 \pm 0.16\right)$, Polygenis pradoi/Oxymycterus $\mathrm{sp} .\left(\mathrm{c}^{2}=6.25 ; \mathrm{C}=0.55 \pm\right.$ $0.19)$ and Amblyopinus sp./Oxymycterus sp. $\left(\mathrm{c}^{2}=\right.$ 13.62; $\mathrm{C}=0.62 \pm 0.47)$. According to Botelho et al. (1981), these values support the recognition of the true hosts for those ectoparasites in a given study area. These results allied with the kariology constitute an important step for correct host identifications.

According to Table II, both the infestations by acari and fleas were higher in April 1991, with the number of infested rodents decreasing from that month on. Grouping the months in seasons (colddry: August 1990, April 1991, June 1991, August 1991; warm-rainy: October 1990, November 1990, December 1990 and March 1991) it can be seen that the total of captured ectoparasites was greater in the cold-dry season, both for fleas and acari (Tables II, IV). Nevertheless, while the percentages for acari were, respectively, $57.2 \%$ (cold-dry) and $42.7 \%$ (warm-rainy), fleas showed a three fold increase in abundance in the cold-dry season: $74.7 \%$ against $25.3 \%$ in the warm-rainy season. Relative to the infestation prevalence, fleas and acari showed different results concerning the number of infested rodents in both seasons, with acari being more prevalent in the warm-rainy season $(100 \%)$ and fleas in the cold-dry season $(65.8 \%)$. Anoplura and Coleoptera, when compared in relation to seasonality, showed alternate distribution, with Hoplopleura species found only in the warmrainy period and Amblyopinus in the cold-dry one (Table IV).

The association between ectoparasites indicated in Table V show the prevalence of double infestations being most common and simple, triple and quadruple ones nearly equivalent in number. By host, the most common infestations were: simple on $O$. nigripes; double, quintuple and sextuple on Oxymycterus sp.; triple and quadruple on $A$. serrensis.

New geographical and host records were found during this work: (a) Hoplopleura sciuricola, found for the second time in Brazil. In the Oswaldo Cruz Collection, a specimen from Caraguatatuba, State of São Paulo (without date and host record) was identified by Werneck. Previous studies have indicated this species occurrence in the United States, Venezuela, Colombia, Peru and Bolivia (Ferris 1951, Johnson 1972); (b) Sciurus aestuans,

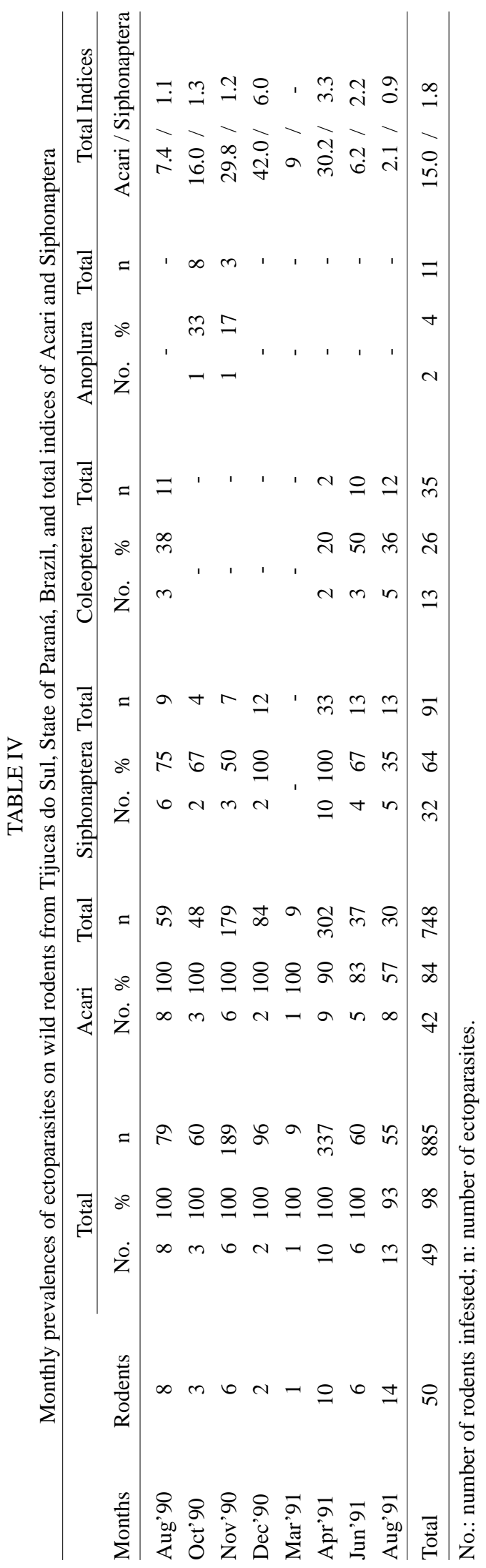




\section{TABLE V}

Simple and multiple infestations of ectoparasites on wild rodents from Tijucas do Sul, State of Paraná, Brazil

\begin{tabular}{|c|c|c|c|c|c|}
\hline Infestation & Ectoparasites (No.) & Hosts (No.) & Infestation & Ectoparasites (No.) & Hosts (No.) \\
\hline \multirow[t]{5}{*}{ Simple: (8) } & $\mathrm{a}(1)$ & $\mathrm{G}(1)$ & & $\mathrm{b}-\mathrm{c}-\mathrm{o}(2)$ & $\mathrm{C}(2)$ \\
\hline & $\mathrm{j}(1)$ & $\mathrm{F}(1)$ & & $\mathrm{b}-\mathrm{c}-\mathrm{p}(1)$ & $\mathrm{C}(1)$ \\
\hline & c (3) & $C(1)-E(2)$ & & $\mathrm{b}-\mathrm{c}-\mathrm{n}(1)$ & $\mathrm{C}(1)$ \\
\hline & d (2) & $\mathrm{E}(1)$ & & $\mathrm{b}-\mathrm{h}-1(1)$ & $\mathrm{H}(1)$ \\
\hline & o (1) & $\mathrm{C}(1)$ & & $\mathrm{b}-\mathrm{n}-\mathrm{o}(1)$ & $\mathrm{C}(1)$ \\
\hline \multirow[t]{12}{*}{ Double: (16) } & $\mathrm{j}-\mathrm{b}(1)$ & $\mathrm{F}(1)$ & & $\mathrm{c}-\mathrm{d}-\mathrm{k}(1)$ & $\mathrm{D}(1)$ \\
\hline & $\mathrm{j}-\mathrm{m}(2)$ & $\mathrm{F}(2)$ & Quadruple: (9) & $\mathrm{j}-\mathrm{c}-\mathrm{m}-\mathrm{n}(1)$ & $\mathrm{F}(1)$ \\
\hline & $\mathrm{j}-\mathrm{n}(1)$ & $\mathrm{F}(1)$ & & $\mathrm{j}-\mathrm{c}-\mathrm{n}-\mathrm{o}(1)$ & A (1) \\
\hline & $\mathrm{j}-\mathrm{o}(1)$ & $\mathrm{F}(1)$ & & $\mathrm{b}-\mathrm{c}-\mathrm{i}-\mathrm{o}(1)$ & $\mathrm{C}(1)$ \\
\hline & $b-c(3)$ & $A(1)-C(2)$ & & $\mathrm{b}-\mathrm{c}-\mathrm{m}-\mathrm{n}(1)$ & $\mathrm{C}(1)$ \\
\hline & $b-g(1)$ & $\mathrm{F}(1)$ & & $\mathrm{b}-\mathrm{c}-\mathrm{m}-\mathrm{o}(1)$ & $\mathrm{C}(1)$ \\
\hline & $c-g(1)$ & $\mathrm{B}(1)$ & & $\mathrm{b}-\mathrm{c}-\mathrm{n}-\mathrm{o}(1)$ & $\mathrm{C}(1)$ \\
\hline & $c-k(2)$ & $A(1)-B(1)$ & & $\mathrm{b}-\mathrm{g}-\mathrm{m}-\mathrm{o}(1)$ & $\mathrm{F}(1)$ \\
\hline & $c-d(1)$ & E (1) & & $\mathrm{b}-\mathrm{g}-\mathrm{n}-\mathrm{o}(1)$ & $\mathrm{F}(1)$ \\
\hline & $d-e(1)$ & $\mathrm{E}(1)$ & & $d-e-f-k(1)$ & $\mathrm{E}(1)$ \\
\hline & $e-f(1)$ & $\mathrm{E}(1)$ & Quintuple: (3) & $\mathrm{j}-\mathrm{b}-\mathrm{c}-\mathrm{n}-\mathrm{o}(2)$ & $A(1)-F(1)$ \\
\hline & $\mathrm{k}-\mathrm{m}(1)$ & A (1) & & $\mathrm{b}-\mathrm{c}-\mathrm{g}-\mathrm{m}-\mathrm{n}(1)$ & $\mathrm{F}(1)$ \\
\hline \multirow[t]{3}{*}{ Triple: (10) } & $\mathrm{j}-\mathrm{c}-\mathrm{k}(1)$ & $\mathrm{B}(1)$ & Sextuple: (3) & $\mathrm{j}-\mathrm{b}-\mathrm{k}-\mathrm{m}-\mathrm{n}-\mathrm{o}(1)$ & $\mathrm{F}(1)$ \\
\hline & $\mathrm{j}-\mathrm{b}-\mathrm{k}(1)$ & $\mathrm{F}(1)$ & & $b-c-d-e-f-o(1)$ & $\mathrm{E}(1)$ \\
\hline & $\mathrm{b}-\mathrm{c}-\mathrm{k}(1)$ & $\mathrm{C}(1)$ & & $\mathrm{b}-\mathrm{g}-\mathrm{k}-\mathrm{m}-\mathrm{n}-\mathrm{o}(1)$ & $\mathrm{F}(1)$ \\
\hline \multicolumn{6}{|c|}{ Legend } \\
\hline
\end{tabular}

\section{Ectoparasites}

\section{Acari}

a Amblyomma aff. cajennense

b Androlaelaps fahrenholzi

c Androlaelaps rotundus

d Gigantolaelaps wolffsohni

e Laelaps paulistanensis

f Mysolaelaps parvispinosus

g Macronyssidae

h Hoplopleura sciuricola

i Hoplopleura imparata Coleoptera

j Amblyopinus sp.

$\mathrm{k} \quad \begin{gathered}\text { Siphonaptera } \\ \text { Craneopsylla minerva }\end{gathered}$
$1 \quad$ Polygenis occidentalis

m Polygenis pradoi

n Polygenis pygaerus

o Polygenis rimatus

$\mathrm{p} \quad$ Polygenis tripus

Hosts

A Akodon sp.

B Akodon montensis

C Akodon serrensis

D Oryzomys flavescens

E Oryzomys nigripes

F Oxymycterus sp.

$\mathrm{G} \quad$ Nectomys squamipes

$\mathrm{H} \quad$ Sciurus aestuans for the first time notified as $H$. sciuricola host, although other species of the same genus can be infested by this louse (Ferris 1951, Johnson 1972); (c) Polygenis (P.) o. occidentalis and Polygenis (N.) pygaerus, although both coexist in Santa Catarina; (d) A. serrensis parasited by Polygenis (P.) tripus.

\section{ACKNOWLEDGEMENTS}

To Mr Pedro Scherer Neto, Museu de História Natural Capão da Imbuia, for the collection opportunity at Panagro Farm.

\section{REFERENCES}

Amorim M, Serra-Freire NM 1996. Morphological description of tick larval stage (Acari: Ixodidae). 3. Amblyomma varius Kock, 1844. Entomologia y vectores 3: 67-81.

Ashe JS, Timm RM 1987. Probable mutualistic association between staphylinid beetles (Amblyopinus) and their rodent hosts. J Trop Ecol 3: 177-181.

Barros-Battesti DM, Arzua M 1997. Geographical distribution by biomes of some marsupial Siphonaptera from the State of Paraná, Brazil. Mem Inst Oswaldo Cruz 92: 485-486.

Barros DM, Baggio D 1992. Ectoparasites (Ixodida Leach, 1817) on wild mammals in the State of Paraná, Brazil. Mem Inst Oswaldo Cruz 87: 291-296.

Barros DM, Linardi PM, Botelho JR 1993. Ectoparasites of some wild rodents from Paraná State, Brazil. J Med Entomol 30: 1068-1070.

Bergallo HG 1991. Dinâmica Populacional, Área de Vida, Parasitismo e Mutualismo de Pequenos Mamíferos da Estação Ecológica da Juréia, SP, MSc 
Thesis, Universidade Estadual de Campinas, Campinas, SP, 121 pp.

Botelho JR 1978. Ectoparasitos de Roedores Silvestres do Município de Caratinga, MG, MSc Thesis, Universidade Federal de Minas Gerais, Belo Horizonte, MG, 143 pp.

Botelho JR, Linardi PM 1996. Interrelações entre ectoparasitos e roedores em ambientes silvestre e urbano de Belo Horizonte, Minas Gerais, Brasil. Rev Bras Entomol 40: 425-430.

Botelho JR, Linardi PM, Williams P, Nagem RL 1981. Alguns hospedeiros reais de ectoparasitos do município de Caratinga, Minas Gerais, Brasil. Mem Inst Oswaldo Cruz, 76: 57-59.

Ferris GF 1951. The sucking lice. Mem Pacif Coast Entomol Soc 1: 1-320.

Ford CE, Hamerton JL 1956. A colchicine hypotonic citrate squash sequence for mammalian chromosomes. Stain Tech 31: 247-251.

Guimarães LR 1945. Sobre alguns ectoparasitos de aves e mamíferos do litoral paranaense. Arq Mus Paranaense 4: 179-190.

Guitton N, Araújo Filho NA, Sherlock IA 1986. Ectoparasitos de roedores e marsupiais no ambiente silvestre de Ilha Grande, Estado do Rio de Janeiro, Brasil. Mem Inst Oswaldo Cruz 81: 233-234.

Johnson PT 1972. Sucking lice of Venezuelan rodents, with remarks on related species (Anoplura). Brigham Young Univ Sci Bull 17: 1-62.

Linardi PM 1987. Distribuição geográfica dos sifonápteros ropalopsilinos. Rev Bras Biol 47: 385-396.

Linardi PM, Guimarães LR 1993. Systematic review of genera and subgenera of Rhopalopsyllinae (Siphonaptera: Rhopalopsyllidae) by phenetic and cladistic methods. J Med Entomol 30: 161-170.

Linardi PM, Botelho JR, Neves DP, Cunha HC 1984. Sobre alguns ectoparasitos de roedores silvestres de Belo Horizonte. Rev Bras Biol 44: 215-219.

Linardi PM, Botelho JR, Rafael JA, Valle CMC, Cunha A, Machado PAR 1991a. Ectoparasitos de pequenos mamíferos da ilha de Maracá, Roraima, Brasil. I.
Ectoparasitofauna, registros geográficos e de hospedeiros. Acta Amazonica 21: 131-140.

Linardi PM, Botelho JR, Ximenez A, Padovani CR 1991b. Notes on ectoparasites of some small mammals from Santa Catarina State, Brazil. J Med Entomol 28: 183-185.

Linardi PM, Teixeira VP, Botelho JR, Ribeiro LS 1987. Ectoparasitos de roedores em ambientes silvestres do município de Juíz de Fora, Minas Gerais. Mem Inst Oswaldo Cruz 82:137-139.

Lopes CML, Linardi PM, Botelho JR 1989. Ectoparasitos de roedores do município de Tiradentes, Minas Gerais. I. Ectoparasitofauna. Mem Inst Oswaldo Cruz 84: 333-334.

Maack R 1968. Geografia Física do Estado do Paraná, 2ed, José Olympio, Rio de Janeiro, 450 pp.

Ribeiro SS 1966/1967. Ixodides encontrados no Paraná. An Fac Med Un Fed Paraná 9/10: 7-51.

Sbalqueiro IJ, Nascimento AP 1996. Occurrence of Akodon cursor (Rodentia, Cricetidae) with 14, 15 and 16 chromosome cytotypes in the same geographic area in Southern Brazil. Braz J Genetics 19: 565-569.

Seabright M 1971. A rapid banding technique for human chromosome. Lancet 2: 971-972.

Seevers CH 1955. A revision of the tribe Amblyopinini: Staphylinid beetles parasitic on mammals. Fieldiana: Zoology 37: 211-264.

Southwood TRE 1971. Ecological Methods with Reference to the Study of Insects Populations, Chapman and Hall, London, $391 \mathrm{pp}$.

Timm RM, Ashe JS 1987. Host and elevational specificity of parasitic beetles (Amblyopinus Solsky) (Coleoptera: Staphylinidae) in Panama. Proc Biol Soc Wash 100: 13-20.

Whitaker Jr JO, Dietz JM 1987. Ectoparasites and other associates of some mammals from Minas Gerais, Brazil. Entomol News 98: 189-197.

Whitaker Jr JO, Mumford RE 1977. Records of ectoparasites from Brazilian mammals. Entomol News 88: 255-258. 
Ectoparasites of Wild Rodents from Paraná - Darci M Barros-Battesti et al. 